\title{
Nonenzymatic Glucose Biosensors Based on Silver Nanoparticles Deposited on $\mathrm{TiO}_{2}$ Nanotubes
}

\author{
Zheng Li, ${ }^{1,2,3}$ Yong Zhang, ${ }^{4}$ Jiaye Ye, ${ }^{1}$ Meiqing Guo, ${ }^{1,3}$ Jing Chen, ${ }^{1}$ and Weiyi Chen ${ }^{2,3}$ \\ ${ }^{1}$ College of Mechanics, Taiyuan University of Technology, Taiyuan 030024, China \\ ${ }^{2}$ Institute of Applied Mechanics and Biomedical Engineering, Taiyuan University of Technology, Taiyuan 030024, China \\ ${ }^{3}$ Shanxi Key Laboratory of Material Strength and Structural Impact, Taiyuan University of Technology, Taiyuan 030024, China \\ ${ }^{4}$ Academic Affairs Office, Taiyuan University of Technology, Taiyuan 030024, China \\ Correspondence should be addressed to Meiqing Guo; gmgg82@sina.com and Jing Chen; 1165059779@qq.com
}

Received 17 September 2015; Revised 7 December 2015; Accepted 13 December 2015

Academic Editor: Thomas Thundat

Copyright (c) 2016 Zheng Li et al. This is an open access article distributed under the Creative Commons Attribution License, which permits unrestricted use, distribution, and reproduction in any medium, provided the original work is properly cited.

\begin{abstract}
In the present research, a nonenzymatic glucose biosensor was fabricated by depositing Ag nanoparticles (Ag-NPs) using in situ chemical reduction method on $\mathrm{TiO}_{2}$ nanotubes which were synthesized by anodic oxidation process. The structure, morphology, and mechanical behaviors of electrode were examined by scanning electron microscopy and nanoindentation. It was found that Ag-NPs remained both inside and outside of $\mathrm{TiO}_{2}$ nanotubes whose length and diameter were about $1.2 \mu \mathrm{m}$ and $120 \mathrm{~nm}$. The composition was constructed as an electrode of nonenzymatic biosensor for glucose oxidation. The electrocatalytic properties of the prepared electrodes for glucose oxidation were investigated by cyclic voltammetry (CVs) and differential pulse voltammetry (DPV). Compared with bare $\mathrm{TiO}_{2}$ and $\mathrm{Ag}$-fresh $\mathrm{TiO}_{2}$ nanotube, $\mathrm{Ag}-\mathrm{TiO}_{2} /\left(500^{\circ} \mathrm{C}\right)$ nanotube exhibited the best electrochemical properties from cyclic voltammetry (CVs) results. Differential pulse voltammetry (DPV) results showed that, at $+0.03 \mathrm{~V}$, the sensitivity of the electrode to glucose oxidation was $3.69 \mathrm{~mA} * \mathrm{~cm}^{-2} * \mathrm{mM}^{-1}$ with a linear range from $20 \mathrm{mM}$ to $190 \mathrm{mM}$ and detection limit of $24 \mu \mathrm{M}$ (signal-to-voice ratio of 3). In addition the nonenzymatic glucose sensors exhibited excellent selectivity, stability, and repeatability.
\end{abstract}

\section{Introduction}

The blood glucose detection is of great significance in the application of food process, clinical medicine, and biology [13]. In particular accurate glucose determination for diabetics can be very effective to the detection and treatment of diabetes mellitus [4]. The glucose oxidase (GOD) analytical method is the first and most commonly used way for glucose detection in clinical trials $[5,6]$. However, the entity of GOD is enzyme which is easily inactive and denatured, resulting in poor stability and repeatability of enzymatic electrodes $[7,8]$.

Nonenzymatic glucose biosensors can avoid that problem because of direct catalyzed oxidation to glucose on the surface of electrode [9-11]. In order to increase specific surface areas and enhance mass transport ability, these electrodes could use nanomaterials as substrates like carbon nanotubes (CNTs) [12], nanowires [13], mesoporous structure [14], and so forth and decorate with mental nanoparticles such as Pt [15], Ni [16], $\mathrm{Ag}[17]$, and $\mathrm{Cu}[18]$.
$\mathrm{TiO}_{2}$ nanotube has been paid more and more attention in chemical reactions and biosensor fields because of their well-aligned nanostructure, large surface area property, thermal stability, chemical inertness, and nontoxicity [19, 20]. Recently, silver doped $\mathrm{TiO}_{2}$ nanocomposite structures have attracted much attention not only because $\mathrm{TiO}_{2}$ is a promising material with desirable electronic, but also because Ag displays some unique activities in chemical and biological sensing compared with the other noble metals such as $\mathrm{Ru}$ and $\mathrm{Pt}$ [19]. However, the electrocatalytic activity of Ag doped $\mathrm{TiO}_{2}$ nanotubes has not been subjected to intensive report.

Many approaches were developed to fabricate different sizes of $\mathrm{Ag}$ doped $\mathrm{TiO}_{2}$ nanotubes such as sol-gel, "wet" chemical, and ceramic methods. However, drying, heating, or annealing at high temperatures is revolved in the preparation process [21, 22]. In order to modify the $\mathrm{TiO}_{2}$ nanotubes by Ag nanoparticles, a polyol method at low temperature has been developed. The polyol process was that using polyol such as diethylene glycol [23] and glycerol [24] both as 
solvent and reducing agent during reaction which can be conduce to the formation of nanostructures. The $\mathrm{Ag}^{+}$ions from silver nitrate $\left(\mathrm{AgNO}_{3}\right)$ can be reduced to metallic Ag. The Ag nanoparticles were deposited successfully on the surface of $\mathrm{TiO}_{2}$. Moreover the specific surface area will be hugely increased by silver nanoparticles deposited on $\mathrm{TiO}_{2}$ nanotubes. So $\mathrm{TiO}_{2}$ nanotubes decorated with silver nanoparticles possess distinct advantages for nonenzymatic glucose sensors.

In this work, the Ag nanoparticles were deposited successfully on the surface of $\mathrm{TiO}_{2}$ by polyol process. Scanning electron microscope (SEM) and nanoindentation were used for characterization. Furthermore, the electrocatalytic activity of the $\mathrm{Ag}-\mathrm{TiO}_{2}$ electrode was also evaluated by cyclic voltammetry (CVs) and differential pulse voltammetry (DPV).

\section{Experimental}

2.1. Reagents. Titanium sheet $(15 \mathrm{~mm} * 10 \mathrm{~mm} * 1 \mathrm{~mm})$ was provided by Tianjin Pengbo Company, China. All of the other chemicals, including glycerol, ammonium fluoride $\left(\mathrm{NH}_{4} \mathrm{~F}\right)$, sodium borohydride $\left(\mathrm{NaBH}_{4}\right)$, silver nitrate $\left(\mathrm{AgNO}_{3}\right)$, $\mathrm{Na}_{2} \mathrm{HPO}_{4}, \mathrm{NaH}_{2} \mathrm{PO}_{4}, \mathrm{H}_{3} \mathrm{PO}_{4}$, poly(vinylpyrrolidone) (PVP), and $\mathrm{KCl}$, were of analytical grade and used as received. A $0.1 \mathrm{M}$ phosphate buffer solution (PBS) prepared using $\mathrm{Na}_{2} \mathrm{HPO}_{4}$ and $\mathrm{NaH}_{2} \mathrm{PO}_{4}$ was employed as supporting electrolyte. The desired $\mathrm{pH}$ of solution was adjusted with $0.1 \mathrm{M}$ $\mathrm{NaOH}$ or $0.1 \mathrm{M} \mathrm{H}_{3} \mathrm{PO}_{4}$. All aqueous solution was prepared with reagent grade chemicals and double distilled water.

2.2. Apparatus. All the electrochemical measurements were performed on a $\mathrm{CH}$ instrument $660 \mathrm{E}$ electrochemical workstation (ChenHua Instruments Co. Ltd., Shanghai, China). Scanning electron microscope (FE-SEM, Hitachi S-4800) was used to determine the morphology and composition of the samples. Nanoindentation (NanoIndenter G200, USA) was used to determine the mechanical properties. All measurements were conducted at room temperature.

2.3. Synthesis of $\mathrm{TiO}_{2}$ Nanotube Arrays on Ti Substrate. Before use, the titanium foils were polished with abrasive paper of 400\#, 600\#, and $800 \#$ until the surfaces were smooth and remained with no scratch and then ultrasonically cleaned in alcohol and double distilled water for $10 \mathrm{~min}$, respectively, and dried in air eventually. Then, titanium sheets were used as the substrate electrode with Pt electrodes as cathode. Samples were anodized in water/glycerol ( $1: 1 \mathrm{Vol} . \%)$ mixtures containing $0.3 \mathrm{M} \mathrm{NH}_{4} \mathrm{~F}$ at a potential of $30 \mathrm{~V}$ for $3 \mathrm{~h}$. Finally, the as-prepared $\mathrm{TiO}_{2}$ nanotube electrode was annealed at $500^{\circ} \mathrm{C}\left(10^{\circ} \mathrm{C} / \mathrm{min}\right)$ under nitrogen atmosphere for $2 \mathrm{~h}$.

2.4. Preparation of $\mathrm{Ag}$ Nanoparticles on $\mathrm{TiO}_{2}$ Nanotubes. $\mathrm{Ag}$ nanoparticles on $\mathrm{TiO}_{2}$ nanotubes were prepared by the following process. Firstly, $1 \mathrm{~mL} \mathrm{AgNO}{ }_{3}(0.04 \mathrm{M})$ was mixed with $10 \mathrm{~mL}$ PVP $(0.01 \mathrm{M})$ and stirred with ice-bath after adding $50 \mathrm{~mL}$ water to the solution. Then, $1 \mathrm{~mL} \mathrm{NaHB}_{4}(0.06 \mathrm{M})$ was dropped quickly into the solution with colour turning brown, by stirring for $10 \mathrm{~min}$. At last, the above-prepared $\mathrm{TiO}_{2}$ nanotubes $\left(500^{\circ} \mathrm{C}\right)$ were entirely immersed in this electrolyte under static conditions for $7 \mathrm{~h}$ and subsequently rinsed with double stilled water and air-dried and then $\mathrm{Ag}-\mathrm{TiO}_{2} /\left(500^{\circ} \mathrm{C}\right)$ was obtained.

2.5. Characterization of Electrocatalytic Properties of $A g$ $\mathrm{TiO}_{2}$ Nanotube Electrode. The electrochemical measurements were carried out with a conventional three-electrode system. The prepared electrode $\left(\mathrm{TiO}_{2}, \mathrm{Ag}-\mathrm{TiO}_{2}\right.$ and $\mathrm{Ag}$ $\left.\mathrm{TiO}_{2} /\left(500^{\circ} \mathrm{C}\right)\right)$ was used as a working electrode with a platinum electrode as an auxiliary electrode and a saturated calomel electrode (SCE) as a reference electrode in all cases.

\section{Results and Discussions}

3.1. Morphology, Composition, and Structure Analysis. The morphologies of the as-formed $\mathrm{TiO}_{2}$ nanotubes, Ag-fresh $\mathrm{TiO}_{2}$, and $\mathrm{Ag}-\mathrm{TiO}_{2} /\left(500^{\circ} \mathrm{C}\right)$ were depicted in Figure 1. Figure 1 (a) showed clearly the prepared vertically aligned $\mathrm{TiO}_{2}$ nanotubes arrays with diameter of $120 \mathrm{~nm}$ and length of $1.2 \mu \mathrm{m}$. It is apparent from Figure 1(b) that the ordered and evenly distributed Ag nanoparticles with average diameter of $20 \mathrm{~nm}$ are formed preferentially on the exterior mouth of the amorphous $\mathrm{TiO}_{2}$ nanotubes. After the nanotubes were annealed at $500^{\circ} \mathrm{C}$, the $\mathrm{Ag}$ nanoparticles were deposited on them under the same method (see Figure 1(c)). Some Ag nanoparticles were dispersed on the pore openings and showed a distribution that is more dense than that in Figure 1(b), while some were deposited into the nanotubes, as indicated by the arrow. It can be presumed that the nanotubes annealed at $500^{\circ} \mathrm{C}$ facilitate the $\mathrm{Ag}$ formation on the tube surface, and the electrocatalytic properties were also improved as discussed later.

3.2. Nanoindentation Properties. In recent years nanoindentation technology has been widely used to measure the hardness and elasticity modulus of medical materials, especially in implants devices [25]. The description of the samples' $\left(\mathrm{TiO}_{2}, \mathrm{Ag}\right.$-fresh $\mathrm{TiO}_{2}$ and $\mathrm{Ag}-\mathrm{TiO}_{2} /\left(500^{\circ} \mathrm{C}\right)$ nanotube) nanomechanical characterization was provided. As observed in Figure 2, the displacement of $\mathrm{Ag}-\mathrm{TiO}_{2} /\left(500^{\circ} \mathrm{C}\right)$ nanotubes was the shortest and $\mathrm{TiO}_{2}$ nanotubes were the longest when loan was selected the same. It was easy to figure out $\mathrm{Ag}-\mathrm{TiO}_{2} /\left(500^{\circ} \mathrm{C}\right)$ nanotubes were the hardest and the reason could be ascribed to two aspects. Compared with nonannealed sample, the higher hardness observed for Ag$\mathrm{TiO}_{2} /\left(500^{\circ} \mathrm{C}\right)$ nanotubes can be due to the higher hardness of anatase and rutile phases for annealed samples at $500^{\circ} \mathrm{C}$. The hardness results obtained for nonannealed sample and annealed sample were similar to those stated in earlier studies [26]. In addition, it may be ascribed to the deposition of Ag nanoparticles. Both inside and outside of nanotubes were attached with Ag-NPs which densified empty space, resulting in fixed enhancement of hardness.

3.3. Electrocatalytic Oxidation of Glucose on the Prepared Electrodes. CVs were used to investigate the catalytic activities of the $\mathrm{Ag}-\mathrm{TiO}_{2} /\left(500^{\circ} \mathrm{C}\right)$ electrode. Figure 3 showed $\mathrm{CVs}$ of 


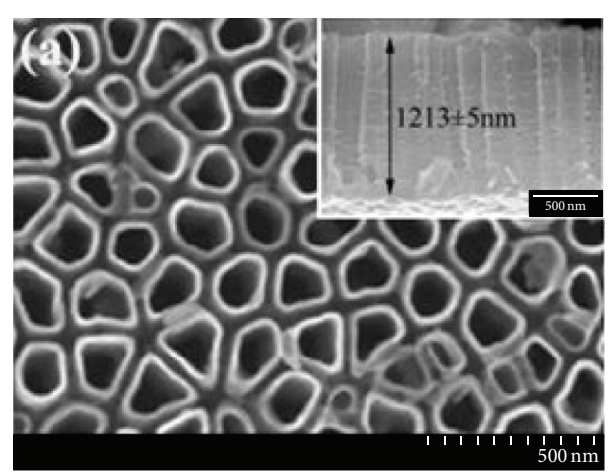

(a)

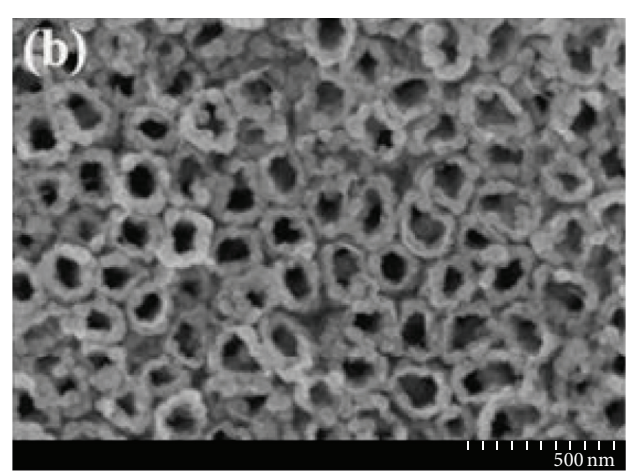

(b)

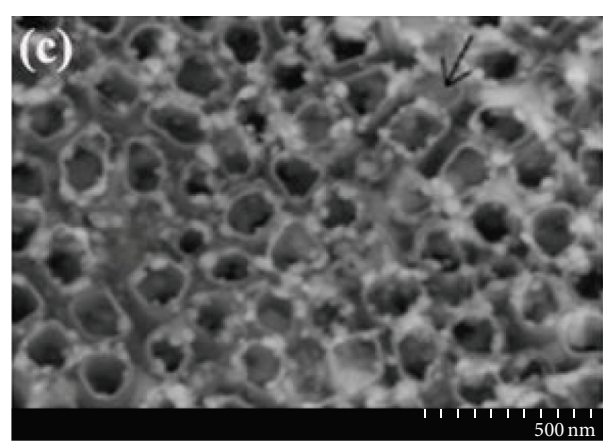

(c)

FIgure 1: SEM images of $\mathrm{TiO}_{2}(\mathrm{a}), \mathrm{Ag}_{-} \mathrm{TiO}_{2}(\mathrm{~b})$, and $\mathrm{Ag}-\mathrm{TiO}_{2}\left(500^{\circ} \mathrm{C}\right)$ (c) nanotube. Inset: the sectional view of TiO .

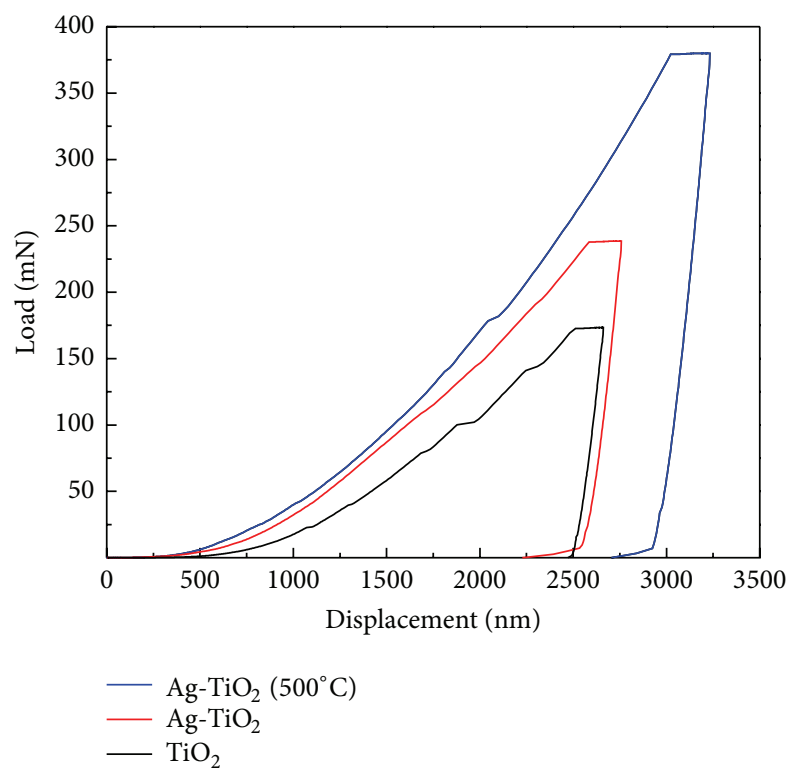

FIGURE 2: Characteristic load versus nanoindentation depth for $\mathrm{TiO}_{2}, \mathrm{Ag}-\mathrm{TiO}_{2}$, and $\mathrm{Ag}-\mathrm{TiO}_{2}\left(500^{\circ} \mathrm{C}\right)$ nanotube.

the as-formed $\mathrm{TiO}_{2}$ nanotube, $\mathrm{Ag}$-fresh $\mathrm{TiO}_{2}$ nanotube, and $\mathrm{Ag}-\mathrm{TiO}_{2} /\left(500^{\circ} \mathrm{C}\right)$ nanotube electrode in the presence and absence of $0.5 \mathrm{M}$ glucose supported by $0.1 \mathrm{M}$ neutral PBS, respectively. Almost no current increase of $\mathrm{TiO}_{2}$ and $\mathrm{Ag}-\mathrm{TiO}_{2}$ nanotubes with glucose addition from Figures 3(a) and 3(b) was observed, which demonstrated that the $\mathrm{TiO}_{2}$ nanotubes and $\mathrm{Ag}-\mathrm{TiO}_{2}$ nanotubes electrode exhibited no electrocatalytic oxidation activity to glucose while $\mathrm{Ag}-\mathrm{TiO}_{2} /\left(500^{\circ} \mathrm{C}\right)$ electrode displayed a pair of redox peaks with the anodic and cathodic peak potential positioned at $+0.03 \mathrm{~V}$ and $-0.3 \mathrm{~V}$ from Figure $3(\mathrm{c})$, which can be ascribed to the oxidation of glucose, indicating that the $\mathrm{Ag}-\mathrm{TiO}_{2} /\left(500^{\circ} \mathrm{C}\right)$ electrode possessed strong catalytic activity towards glucose. There were two possible explanations for this result. The first possibility was relatively weak adherence of Ag nanoparticles onto the nonannealed nanotubular surfaces. The other possibility was that a small amount of silver titanates were obtained by depositing Ag nanoparticles on the $\mathrm{TiO}_{2} / 500^{\circ} \mathrm{C}$ nanotubes, which indicated that the $\mathrm{Ag}$ can not only be deposited but also be doped in the $\mathrm{TiO}_{2}$ nanotubes. The crystal structure distortion increased state density of $\mathrm{Ag}-\mathrm{TiO}_{2} / 500^{\circ} \mathrm{C}$ coating, facilitating the migration of charge carriers, and enhanced catalytic activity [19].

Figure 4 showed $\mathrm{CVs}$ of $\mathrm{Ag}-\mathrm{TiO}_{2} /\left(500^{\circ} \mathrm{C}\right)$ nanotube electrode in $0.5 \mathrm{M}$ glucose supported by $0.1 \mathrm{M}$ neutral PBS, $0.1 \mathrm{M} \mathrm{H}_{2} \mathrm{SO}_{4}$, and $0.1 \mathrm{M} \mathrm{NaOH}$. As observed in Figure 4, compared with CVs in $0.1 \mathrm{M} \mathrm{H}_{2} \mathrm{SO}_{4}$ and $0.1 \mathrm{M} \mathrm{NaOH}$, CVs of $\mathrm{Ag}-\mathrm{TiO}_{2} /\left(500^{\circ} \mathrm{C}\right)$ nanotube electrode in PBS exhibited two oxidation peaks related to the oxidation of glucose, which indicated excellent electrochemical behavior.

Figure 5 showed $\mathrm{CV}$ s of the $\mathrm{Ag}-\mathrm{TiO}_{2} /\left(500^{\circ} \mathrm{C}\right)$ nanotube electrode in blank solution and $0.5 \mathrm{M}$ glucose with the presence of $0.12 \mathrm{M} \mathrm{NaCl}$ and without the presence of $0.12 \mathrm{M}$ $\mathrm{NaCl}$ supported by $0.1 \mathrm{M}$ neutral PBS. $\mathrm{Cl}$ ion was the 


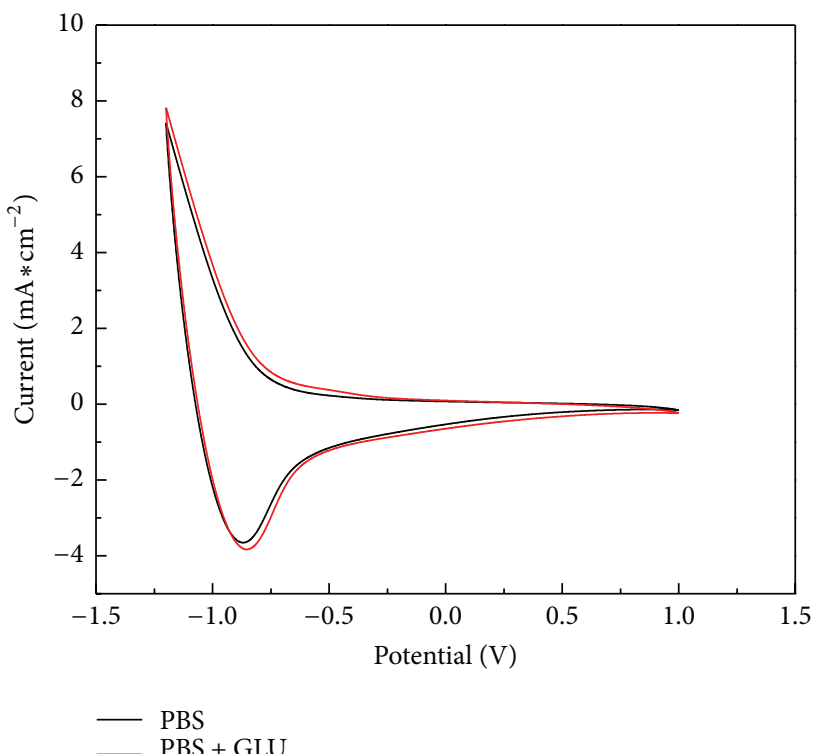

(a)

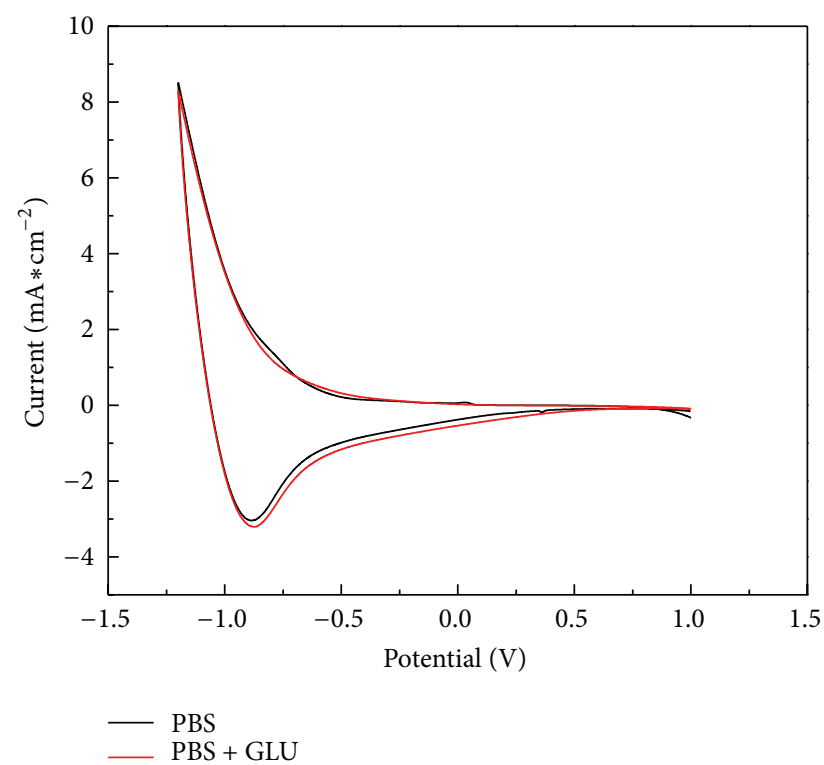

(b)

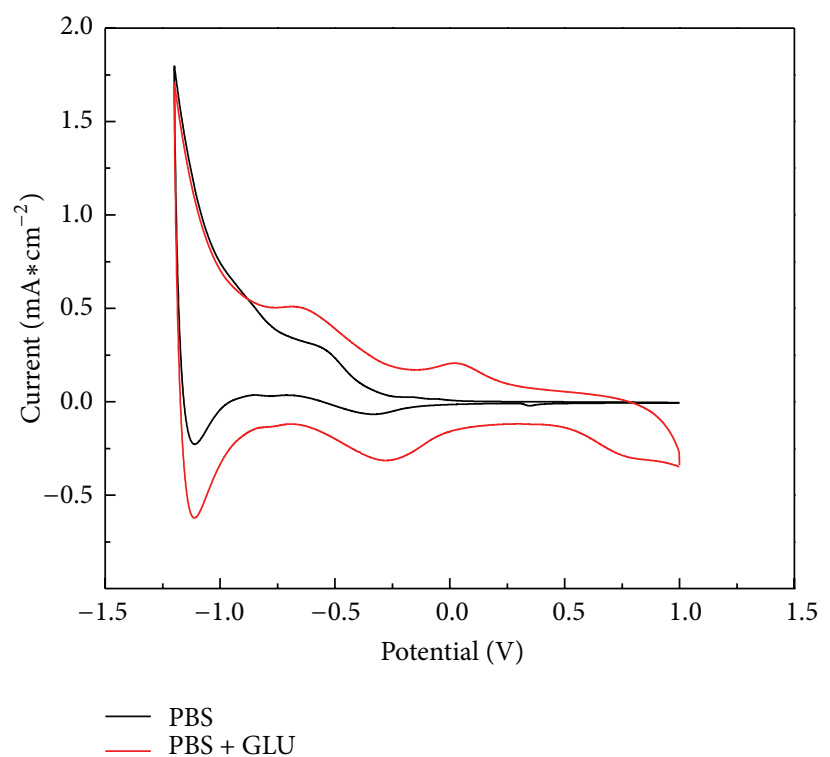

(c)

Figure 3: $\mathrm{CVs}$ of $\mathrm{TiO}_{2}(\mathrm{a}), \mathrm{Ag}-\mathrm{TiO}_{2}(\mathrm{~b})$, and $\mathrm{Ag}-\mathrm{TiO}_{2}\left(500^{\circ} \mathrm{C}\right.$ ) (c) electrode in $0.1 \mathrm{M}$ neutral PBS with (red line) or without (black line) $0.2 \mathrm{M}$ glucose.

usual interfering ion which was preferentially absorbed on the surface of electrodes, resulting in toxicosis and losing electrocatalytic property. As observed in Figure 5, in the blank PBS solution, CVs were characterized by hydrogen adsorption/desorption peaks at negative potentials and a flat double layer region at positive potentials. After $0.5 \mathrm{M}$ glucose was added, an obvious redox peak appeared from $-0.3 \mathrm{~V}$ to $+0.03 \mathrm{~V}$, proving excellent electrocatalytic oxidation ability, whereas in the presence of chloride ions, when $\mathrm{Cl}$ ions were dropped into the solution, the redox peak vanished and the oxidation of glucose was suppressed, which could be attributed to the adsorbing of $\mathrm{Cl}^{-}$preferentially compared with glucose.
According to the adsorption theory proposed by Wang et al. [27], it could be deduced that when there were no $\mathrm{Cl}$ ions in the solution, glucose molecules would adsorb on the surface of $\mathrm{Ag}-\mathrm{TiO}_{2} /\left(500^{\circ} \mathrm{C}\right)$ nanotube electrode in the first place, forming glucose intermediates. During the potential scanned from $-0.3 \mathrm{~V}$ to $+0.03 \mathrm{~V}$ gradually, the intermediates were oxidized leading to current increasing. When potential was over $+0.03 \mathrm{~V}$, the oxidized intermediates were absorbed on the surface, covering the active sites of electrode and decreasing current. When large amounts of chloride ions were present, the poisoning $\mathrm{Ag}$ $\mathrm{TiO}_{2} /\left(500^{\circ} \mathrm{C}\right)$ nanotube electrode showed no electrocatalytic properties. 


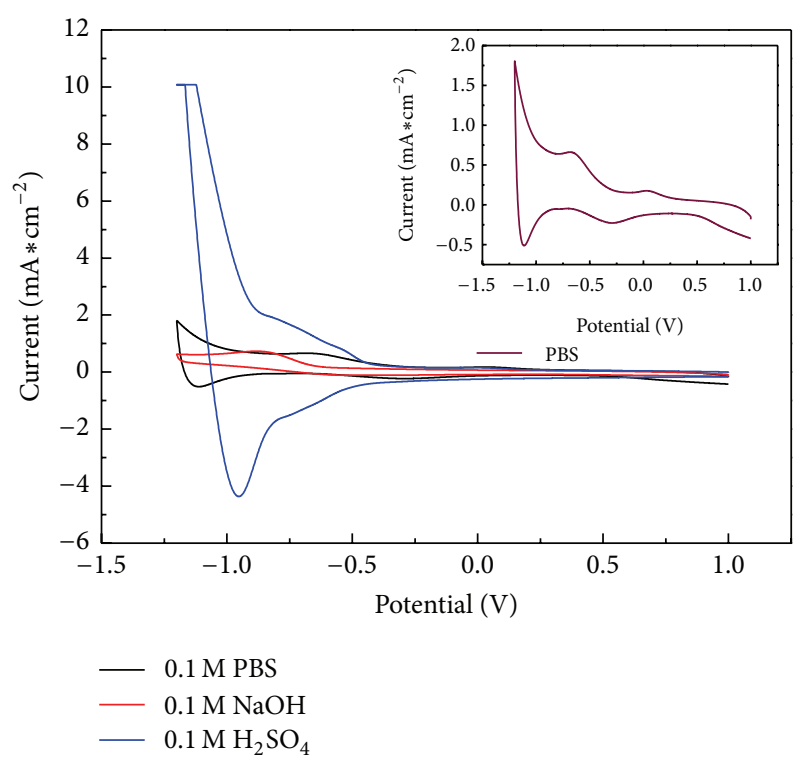

Figure 4: $\mathrm{CVs}$ of $\mathrm{Ag}-\mathrm{TiO}_{2}\left(500^{\circ} \mathrm{C}\right)$ nanotube electrode in $0.5 \mathrm{M}$ glucose supported by $0.1 \mathrm{M}$ neutral $\mathrm{PBS}, 0.1 \mathrm{M} \mathrm{H}_{2} \mathrm{SO}_{4}$, and $0.1 \mathrm{M}$ $\mathrm{NaOH}$.

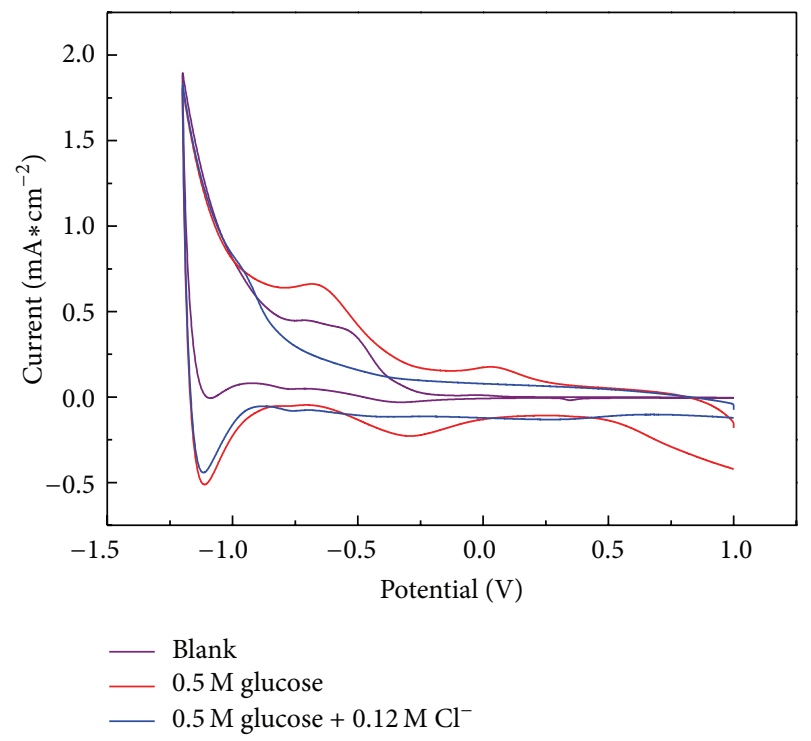

Figure 5: CVs of $\mathrm{Ag}-\mathrm{TiO}_{2}\left(500^{\circ} \mathrm{C}\right)$ nanotube electrode in blank solution, $0.5 \mathrm{M}$ glucose with the presence of $0.12 \mathrm{M} \mathrm{NaCl}$ and $0.5 \mathrm{M}$ glucose without the presence of $0.12 \mathrm{M} \mathrm{NaCl}$ supported by $0.1 \mathrm{M}$ neutral PBS.

3.4. Amperometric Performance of $\mathrm{Ag}-\mathrm{TiO}_{2} /\left(500^{\circ} \mathrm{C}\right) \mathrm{Nan}$ otube Electrode to Glucose Oxidation. Differential pulse voltammetry (DPV) was used to determine the sensor outputs at different glucose concentrations. Figure 6 presented the relationship between currents and variation concentrations of glucose. The prepared electrode exhibited linearity for glucose sensing that ranged from $20 \mathrm{mM}$ to $190 \mathrm{mM}$ with a correlation coefficient of 0.9993 . The electrode sensitivity calculated from the slope of the calibration curve was $3.69 \mathrm{~mA} * \mathrm{~cm}^{-2} * \mathrm{mM}^{-1}$ with the detection limit of $24 \mu \mathrm{M}$.

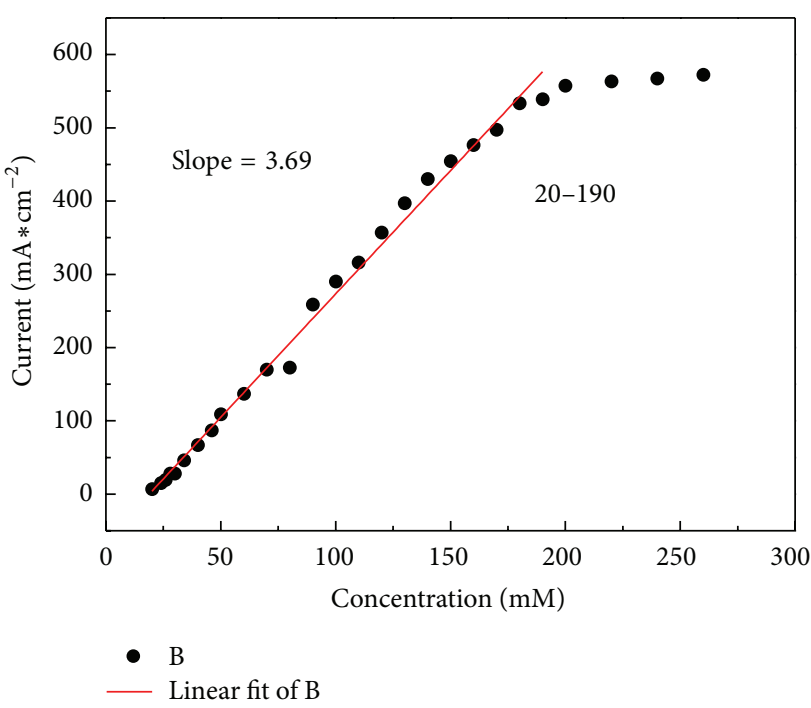

Figure 6: Calibration curve for the amperometric responses of the $\mathrm{Ag}-\mathrm{TiO}_{2}\left(500^{\circ} \mathrm{C}\right)$ nanotube electrode to glucose.

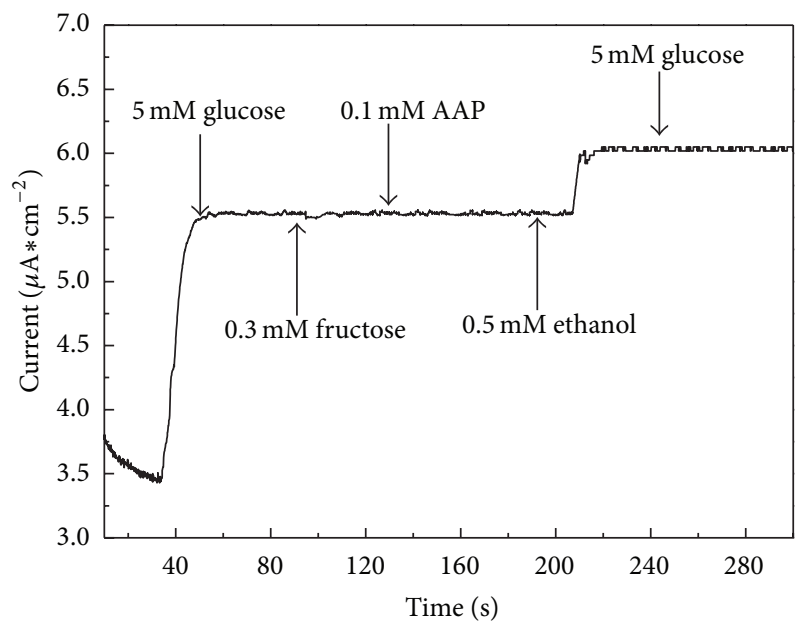

FIgURE 7: The influence of electroactive compounds (ethanol, fructose, and AAP) on the response of $5.0 \mathrm{mM}$ glucose.

Ascorbic acid (AA), uric acid (UA), sucrose, fructose, dopamine, ethanol, and acetaminophen (AAP) were the commonly interfering biomolecules which coexist with glucose in the human blood. To evaluate the selectivity of the $\mathrm{Ag}-\mathrm{TiO}_{2} /\left(500^{\circ} \mathrm{C}\right)$ nanotube electrode, the current responses to ethanol, fructose, and AAP were examined. As shown in Figure 7, it was observed that the response signals of ethanol, fructose, and AAP were negligible for glucose determination. The good selectivity of the nonenzymatic sensor was related to the proper working potential used.

The reproducibility and stability of response current of the $\mathrm{Ag}-\mathrm{TiO}_{2} /\left(500^{\circ} \mathrm{C}\right)$ nanotube electrode were studied. The amperometric response of 10 different $\mathrm{Ag}-\mathrm{TiO}_{2} /\left(500^{\circ} \mathrm{C}\right)$ nanotube electrodes to $1.0 \mathrm{mM}$ glucose was tested independently. As shown in Figure 8, the relative standard deviation (RSD) was $1.5 \%$ for 10 successive measurements, revealing that the 


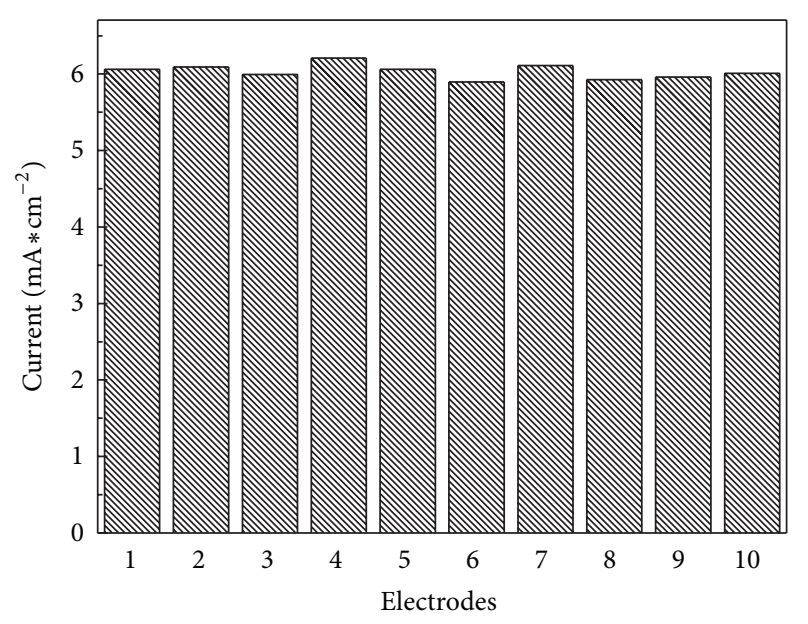

Figure 8: Current response of 10 different $\mathrm{Ag}-\mathrm{TiO}_{2}\left(500^{\circ} \mathrm{C}\right)$ nanotube electrodes to $1.0 \mathrm{mM}$ glucose in PBS (7.0).

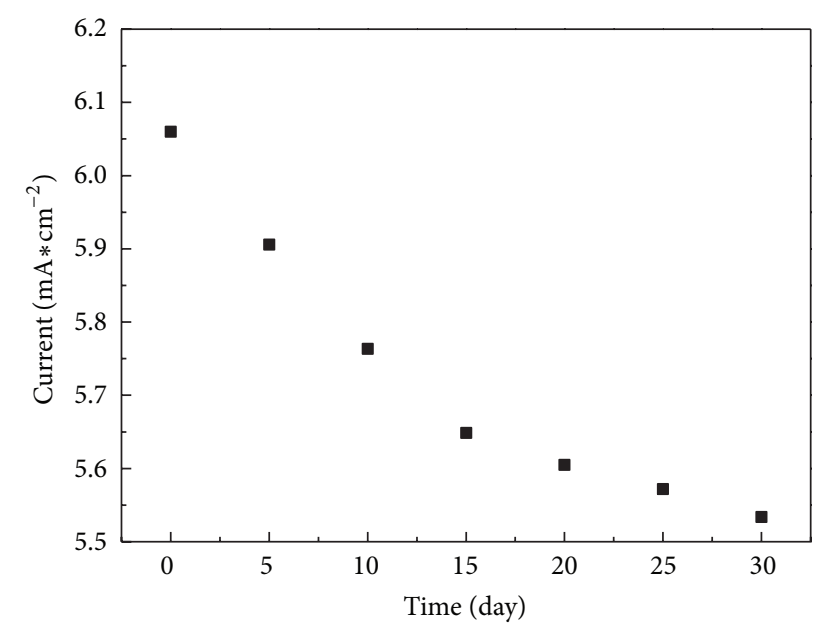

Figure 9: Current response of the $\mathrm{Ag}-\mathrm{TiO}_{2}\left(500^{\circ} \mathrm{C}\right)$ nanotube electrode to $10 \mathrm{mM}$ glucose after storing for different days.

preparation method was acceptably reproducible. The longterm stability was explored by measuring a glucose solution, and the electrode was stored at room temperature. Figure 9 showed that the response current maintained about 92\% of the initial value after 30 days, demonstrating the good stability of the $\mathrm{Ag}-\mathrm{TiO}_{2} /\left(500^{\circ} \mathrm{C}\right)$ nanotube electrode based nonenzymatic glucose biosensor.

\section{Conclusions}

In this work, a simple and effective way to prepare $\mathrm{Ag}$ nanoparticles deposited on the surface of $\mathrm{TiO}_{2}$ nanotube was developed. The Ag deposited and annealing processes made $\mathrm{TiO}_{2}$ nanotube harder which was conducive to the application of tough condition. The electrochemical results demonstrated that the prepared $\mathrm{Ag}-\mathrm{TiO}_{2} /\left(500^{\circ} \mathrm{C}\right)$ nanotube electrode possessed excellent electrocatalytic performance. The constructed nonenzymatic glucose biosensor exhibited good selectivity, stability, and reproducibility. Because of the simple preparation method and good catalytic performance, such material has potential application in catalysis and sensor areas.

\section{Competing Interests}

The authors declare that they have no competing interests.

\section{Acknowledgments}

The authors gratefully acknowledge the financial support from the Natural Science Foundation of China (Grant nos. 51301117 and 31271005) and the Natural Science Foundation for Young Scientists of Shanxi Province, China (Grant nos. 2013021003-1 and 2013021013-5).

\section{References}

[1] Y. Ding, Y. Wang, L. Su, H. Zhang, and Y. Lei, "Preparation and characterization of NiO-Ag nanofibers, $\mathrm{NiO}$ nanofibers, and porous Ag: towards the development of a highly sensitive and selective non-enzymatic glucose sensor," Journal of Materials Chemistry, vol. 20, no. 44, pp. 9918-9926, 2010.

[2] V. Poitout, D. Moatti-Sirat, G. Reach et al., "A glucose monitoring system for on line estimation in man of blood glucose concentration using a miniaturized glucose sensor implanted in the subcutaneous tissue and a wearable control unit," Diabetologia, vol. 36, no. 7, pp. 658-663, 1993.

[3] X. Cao, N. Wang, S. Jia, and Y. Shao, "Detection of glucose based on bimetallic PtCu nanochains modified electrodes," Analytical Chemistry, vol. 85, no. 10, pp. 5040-5046, 2013.

[4] E. Reitz, W. Jia, M. Gentile, Y. Wang, and Y. Lei, "CuO nanospheres based nonenzymatic glucose sensor," Electroanalysis, vol. 20, no. 22, pp. 2482-2486, 2008.

[5] L. C. Clark Jr. and J. C. Lyons, "Electrode systems for continuous monitoring in cardiovascular surgery," Annals of the New York Academy of Sciences, vol. 102, pp. 29-45, 1962.

[6] A. Riklin, E. Katz, I. Willner, A. Stocker, and A. F. Buckmann, "Improving enzyme-electrode contacts by redox modification of cofactors," Nature, vol. 376, no. 6542, pp. 672-675, 1995.

[7] Y. B. Vassilyev, O. A. Khazova, and N. N. Nikolaeva, "Kinetics and mechanism of glucose electrooxidation on different electrode-catalysts. Part I. Adsorption and oxidation on platinum," Journal of Electroanalytical Chemistry, vol. 196, no. 1, pp. 105-125, 1985.

[8] B. Beden, F. Largeaud, K. B. Kokoh, and C. Lamy, "Fourier transform infrared reflectance spectroscopic investigation of the electrocatalytic oxidation of D-glucose: identification of reactive intermediates and reaction products," Electrochimica Acta, vol. 41, no. 5, pp. 701-709, 1996.

[9] L. M. Lu, L. Zhang, F. L. Qu et al., "A nano-Ni based ultrasensitive nonenzymatic electrochemical sensor for glucose: enhancing sensitivity through a nanowire array strategy," Biosensors and Bioelectronics, vol. 25, no. 1, pp. 218-223, 2009.

[10] L. Meng, J. Jin, G. X. Yang, T. H. Lu, H. Zhang, and C. X. Cai, "Nonenzymatic electrochemical detection of glucose based on palladium-single-walled carbon nanotube hybrid nanostructures," Analytical Chemistry, vol. 81, no. 17, pp. 72717280, 2009.

[11] F. Xiao, F. Q. Zhao, D. P. Mei, Z. R. Mo, and B. Z. Zeng, "Nonenzymatic glucose sensor based on ultrasonic-electrodeposition 
of bimetallic PtM ( $\mathrm{M}=\mathrm{Ru}, \mathrm{Pd}$ and $\mathrm{Au})$ nanoparticles on carbon nanotubes-ionic liquid composite film," Biosensors and Bioelectronics, vol. 24, no. 12, pp. 3481-3486, 2009.

[12] J.-S. Ye, Y. Wen, W. D. Zhang, L. M. Gan, G. Q. Xu, and F.-S. Sheu, "Nonenzymatic glucose detection using multi-walled carbon nanotube electrodes," Electrochemistry Communications, vol. 6, no. 1, pp. 66-70, 2004.

[13] C. Y. Guo, H. H. Huo, X. Han, C. L. Xu, and H. L. Li, "Ni/CdS bifunctional $\mathrm{Ti} @ \mathrm{TiO}_{2}$ core-shell nanowire electrode for highperformance nonenzymatic glucose sensing," Analytical Chemistry, vol. 86, no. 1, pp. 876-883, 2014.

[14] H.-K. Seo, D.-J. Park, and J.-Y. Park, "Fabrication and characterization of platinum black and mesoporous platinum electrodes for in-vivo and continuously monitoring electrochemical sensor applications," Thin Solid Films, vol. 516, no. 16, pp. 52275230, 2008.

[15] D. Rathod, C. Dickinson, D. Egan, and E. Dempsey, "Platinum nanoparticle decoration of carbon materials with applications in non-enzymatic glucose sensing," Sensors and Actuators, B: Chemical, vol. 143, no. 2, pp. 547-554, 2010.

[16] J. H. Zhu, J. Jiang, J. P. Liu et al., "CNT-network modified Ni nanostructured arrays for high performance non-enzymatic glucose sensors," RSC Advances, vol. 1, no. 6, pp. 1020-1025, 2011.

[17] A. Baciu, A. Pop, A. Remes, F. Manea, and G. Burtica, "Nonenzymatic electrochemical determination of glucose on silverdoped zeolite-CNT composite electrode," Advanced Science, Engineering and Medicine, vol. 3, no. 1-2, pp. 13-19, 2011.

[18] L.-M. Lu, X.-B. Zhang, G.-L. Shen, and R.-Q. Yu, "Seedmediated synthesis of copper nanoparticles on carbon nanotubes and their application in nonenzymatic glucose biosensors," Analytica Chimica Acta, vol. 715, pp. 99-104, 2012.

[19] Y. Q. Liang, Z. D. Cui, S. L. Zhu, Y. Liu, and X. J. Yang, "Silver nanoparticles supported on $\mathrm{TiO}_{2}$ nanotubes as active catalysts for ethanol oxidation," Journal of Catalysis, vol. 278, no. 2, pp. 276-287, 2011.

[20] Y. Q. Liang, Z. D. Cui, S. L. Zhu, and X. J. Yang, "Formation and characterization of iron oxide nanoparticles loaded on selforganized $\mathrm{TiO}_{2}$ nanotubes," Electrochimica Acta, vol. 55, no. 18, pp. $5245-5252,2010$.

[21] J. Joo, S. G. Kwon, T. Yu et al., "Large-scale synthesis of $\mathrm{TiO}_{2}$ nanorods via nonhydrolytic sol-gel ester elimination reaction and their application to photocatalytic inactivation of E. coli," Journal of Physical Chemistry B, vol. 109, no. 32, pp. 15297-15302, 2005.

[22] S. Yoo, S. A. Akbar, and K. H. Sandhage, "Nanocarving of bulk titania crystals into oriented arrays of single-crystal nanofibers via reaction with hydrogen-bearing gas," Advanced Materials, vol. 16, no. 3, pp. 260-264, 2004.

[23] Y. Yu, L.-L. Ma, W.-Y. Huang, J.-L. Li, P.-K. Wong, and J. C. $\mathrm{Yu}$, "Coating MWNTs with $\mathrm{Cu}_{2} \mathrm{O}$ of different morphology by a polyol process," Journal of Solid State Chemistry, vol. 178, no. 5, pp. 1488-1494, 2005.

[24] P. V. Suneesh, V. S. Vargis, T. Ramachandran, B. G. Nair, and T. G. Satheesh Babu, "Co-Cu alloy nanoparticles decorated $\mathrm{TiO}_{2}$ nanotube arrays for highly sensitive and selective nonenzymatic sensing of glucose," Sensors and Actuators B: Chemical, vol. 215, pp. 337-344, 2015.

[25] S. A. Catledge, J. Borham, Y. K. Vohra, W. R. Lacefield, and J. E. Lemons, "Nanoindentation hardness and adhesion investigations of vapor deposited nanostructured diamond films," Journal of Applied Physics, vol. 91, no. 8, pp. 5347-5352, 2002.
[26] E. Zalnezhad, A. M. S. Hamouda, G. Faraji, and S. Shamshirband, " $\mathrm{TiO}_{2}$ nanotube coating on stainless steel 304 for biomedical applications," Ceramics International, vol. 41, no. 2, pp. 2785-2793, 2015.

[27] J. P. Wang, D. F. Thomas, and A. C. Chen, "Nonenzymatic electrochemical glucose sensor based on nanoporous $\mathrm{PtPb}$ networks," Analytical Chemistry, vol. 80, no. 4, pp. 997-1004, 2008 . 

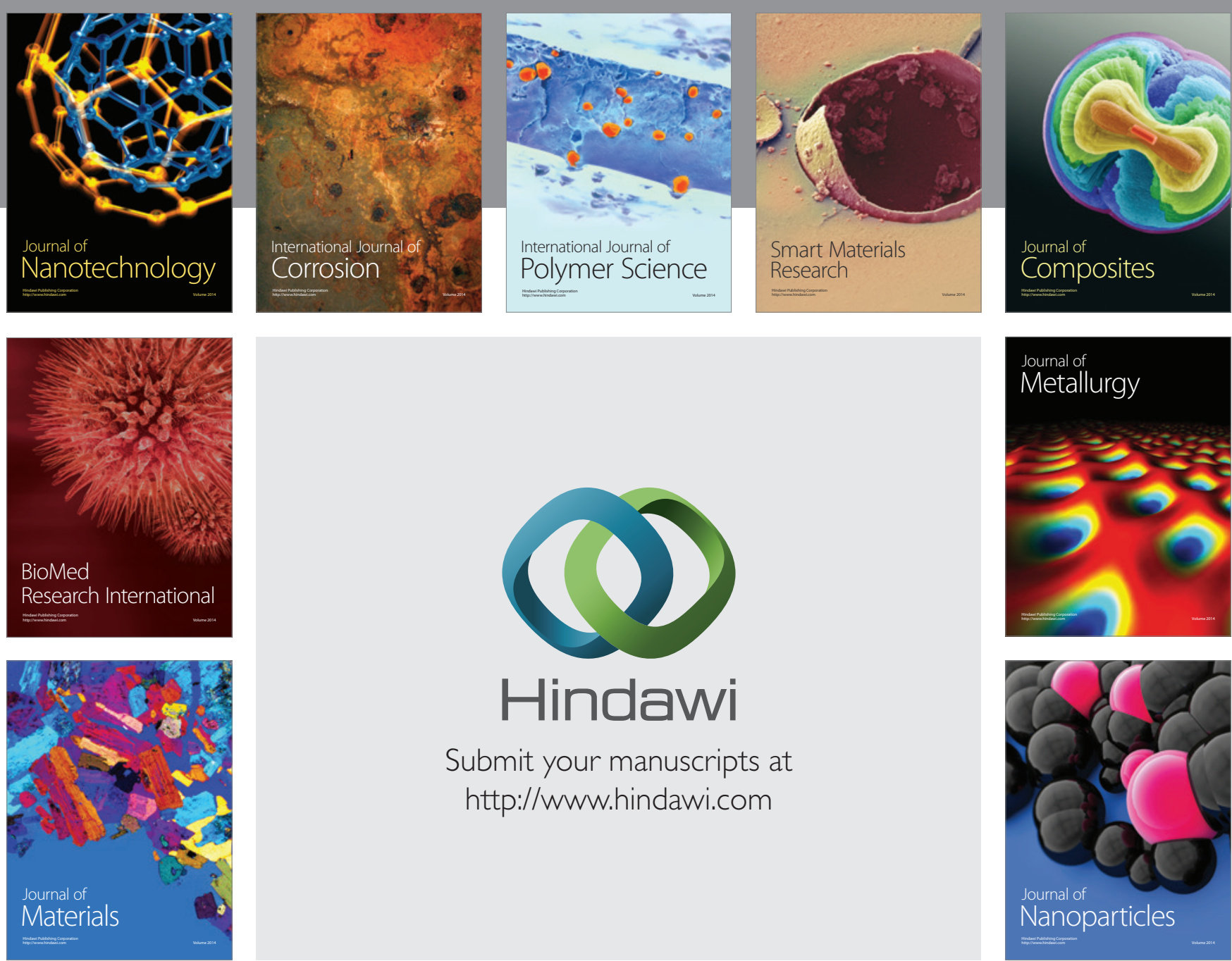

\section{Hindawi}

Submit your manuscripts at

http://www.hindawi.com

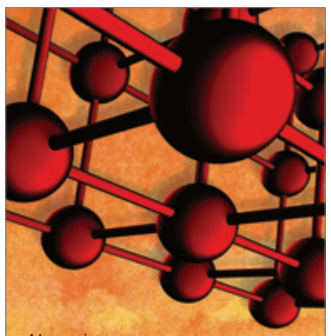

Materials Science and Engineering
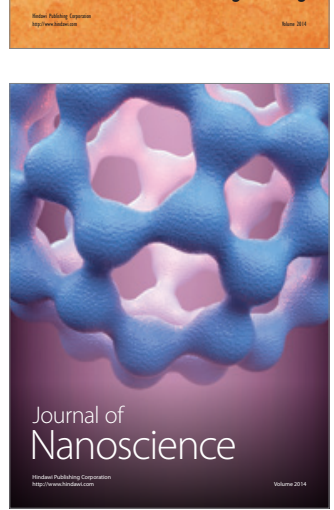
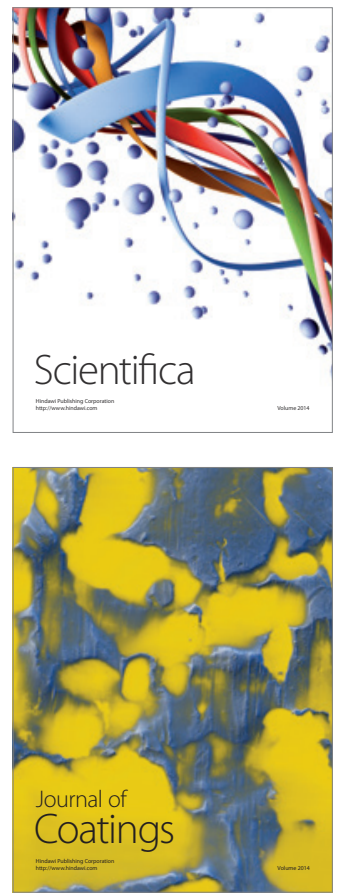
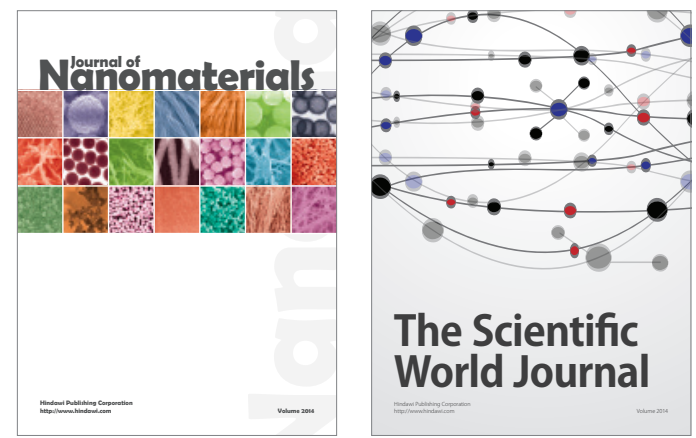

The Scientific World Journal
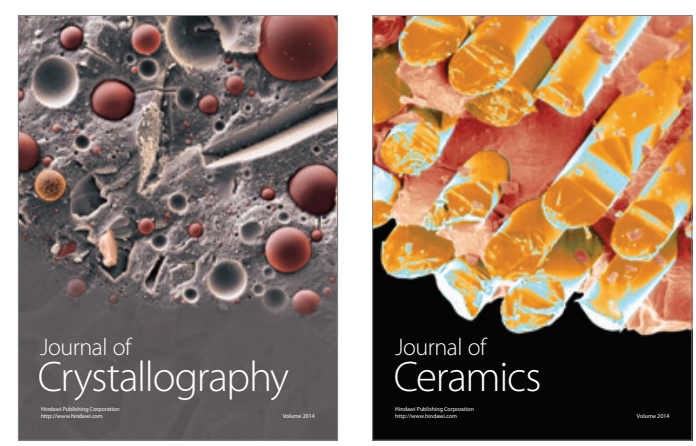
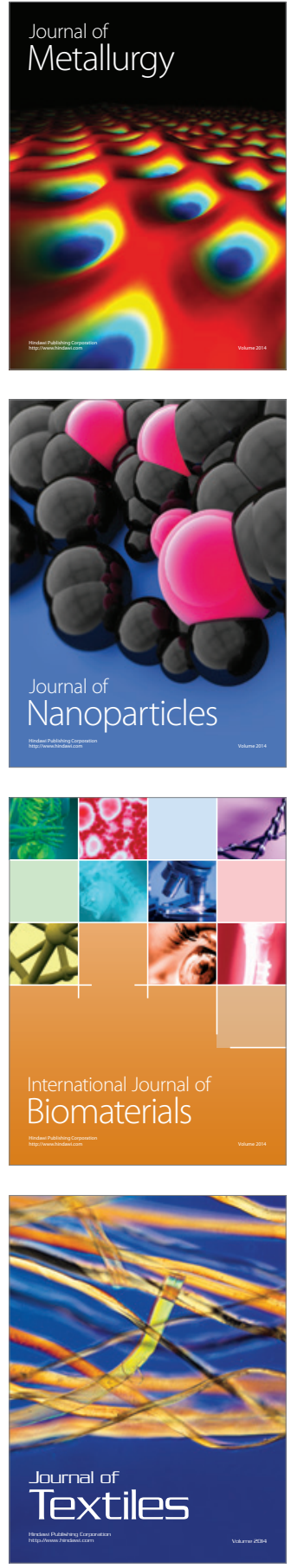